\title{
Ornamental trade as a pathway for Australian redclaw crayfish introduction and establishment
}

\author{
Christina C. Belle ${ }^{1,2}$, Jason Q. H. Wong ${ }^{3}$, Darren C. J. Yeo ${ }^{1}$, S. H. Tan ${ }^{3}$, \\ Heok H. Tan ${ }^{3}$, Esther Clews ${ }^{1}$, Peter A. Todd ${ }^{1, *}$ \\ ${ }^{1}$ Department of Biological Sciences, National University of Singapore, 14 Science Drive 4, Singapore 117543, Singapore \\ ${ }^{2}$ Tropical Marine Science Institute, National University of Singapore, 18 Kent Ridge Road, Singapore 119227, Singapore \\ ${ }^{3}$ Raffles Museum of Biodiversity Research, Department of Biological Sciences, National University of Singapore, \\ 6 Science Drive 2, Singapore 117546, Singapore
}

\begin{abstract}
The ornamental trade is one of the major vectors of freshwater animal species translocation worldwide. The Australian redclaw crayfish Cherax quadricarinatus was brought into Singapore through the trade and culture of aquarium specimens during the late 1980s. From 2000 to the present, redclaw crayfish have been observed in at least 3 of Singapore's 13 reservoirs, including 2 inland reservoirs in the Central Catchment Nature Reserve (CCNR). The current paper presents the first in situ population data of feral C. quadricarinatus populations originating from ornamental trade and includes updated distribution records in Singapore based on recent surveys and museum samples. We report a C. quadricarinatus range expansion in 2 additional reservoirs (1 coastal and 1 inland), and the presence of multiple size cohorts confirms the establishment of reproducing populations in 2 coastal reservoirs and 1 CCNR reservoir. This is alarming as the current distribution borders Singapore's oldest and arguably most important nature reserve (Bukit Timah Nature Reserve: BTNR) and encircles the single remaining substantial freshwater swamp forest in the country (Nee Soon). The Nee Soon swamp forest and BTNR have extremely high conservation value as both areas together harbour the richest native freshwater fauna and flora of the island. Therefore, any range expansion of C. quadricarinatus in Singapore may have severe impacts on its native freshwater fauna and demands immediate attention. As C. quadricarinatus is one of the many invasive freshwater species occurring from the aquarium trade in Singapore, we argue that trade control might prevent further establishment of ornamentals.
\end{abstract}

KEY WORDS: Cherax quadricarinatus - Invasive - Ornamental trade $\cdot$ Reproducing feral populations · Singapore reservoirs

Resale or republication not permitted without written consent of the publisher

\section{INTRODUCTION}

In both terrestrial and aquatic ecosystems, the ornamental trade is one of the most important vectors of species translocation worldwide (Courtenay \& Robins 1975, Mack et al. 2000, Semmens et al. 2004, DehnenSchmutz et al. 2007). Singapore is a major international hub for the aquarium species trade. For instance, in 2008,297 aquarium or pet shops were registered island-wide, and ornamental fish worth \$95 million were exported to more than 80 countries (AVA 2010).
Locally, breeding and keeping exotic aquarium animal species is a popular hobby ( $\mathrm{Ng}$ et al. 1993, Goh \& O'Riordan 2007, Ng et al. 2009). Almost the entire traded and kept aquarium species originate from the tropics or neo-tropics (AVA 2010), which facilitates their establishment in Singapore's tropical water bodies if the species are deliberately or accidentally released.

Introduced freshwater organisms were first noted in Singapore as far back as 1961, when at least 8 exotic fish species were recorded (Alfred 1961, 1966). A first comprehensive review on the status and impact of 
introduced freshwater animals was published by $\mathrm{Ng}$ et al. (1993), who reported 33 fish, 5 turtle, 2 crustacean and 3 mollusc species, originating from ornamental trade, had become established or feral in Singapore. Subsequent publications suggested that the number was even greater, for example, 2 molluscs, 2 freshwater fish and 1 crustacean species were added to the list between 2006 and 2009 (Clements et al. 2006, Ahyong \& Yeo 2007, Tan \& Lim 2008, Ng et al. 2009). Most recently, a series of reviews and species checklists recorded as many as 98 exotic freshwater species in Singapore, including 64 species of fishes, 24 herptiles, 6 molluscs and 4 decapod crustaceans, with many of these believed to have originated from ornamental trade imports (Ng \& Lim 2010, Ng \& Tan 2010, Yeo 2010, Yeo \& Chia 2010).

Cherax quadricarinatus (von Martens, 1868), a large and conspicuously coloured freshwater crayfish of the family Parastacidae, is globally one of the most widely distributed aquaculture and aquarium species (Lawrence \& Jones 2002). It is native to tropical river catchments in northern Australia and southeastern Papua New Guinea, inhabiting all major rivers that flow into the Timor Sea east of Darwin and the Gulf of Carpentaria. C. quadricarinatus displays a considerable degree of phenotypic variability throughout its native range, has an exceptional growth rate, is easy to breed in captivity, and has the capability to survive and reproduce in a wide variety of biotic and abiotic conditions from tropical to temperate zones (Karplus et al. 1998, Lawrence \& Jones 2002). Due to this combination of characteristics, C. quadricarinatus has been relocated worldwide for aquaculture (Jones 1990, Lawrence \& Jones 2002). Best breeding results are obtained if the stock is cultured in open earthen ponds (Jones 1995, Karplus et al. 1998, Rodriguez-Canto et al. 2002), a method that facilitates accidental escape and potential establishment of feral populations in adventive areas. Originating from aquaculture, C. quadricarinatus has managed to establish non-native populations in at least 5 countries, including Jamaica, Mexico, Puerto Rico, South Africa and Australia (domestic translocations) (Williams et al. 2001, de Moor 2002, Doupé et al. 2004, Bortolini et al. 2006, Townsend \& Newell 2006).

Owing to its bright coloration, the second major invasion pathway of Cherax quadricarinatus is the ornamental aquarium pet trade, assisted by the ready availability of this crayfish via pet shops and the Internet. Trade is usually not regulated, as the risk of C. quadricarinatus establishment, for example, in temperate regions, is considered very low (Holdich \& Pöckel 2005), and, so far, no naturalization of C. quadricarinatus originating from the ornamental pet trade has been documented. In Singapore, the redclaw crayfish is readily available in aquarium shops and wet markets at prices ranging from US\$ 0.75 per animal for juveniles to US\$ 2.50 for mature adult individuals, which makes the species easily obtainable by the public.

In 2007, feral Cherax quadricarinatus populations were reported for the first time in Singapore reservoirs (Lower Peirce, Upper Seletar and Kranji), though no population data were available (Ahyong \& Yeo 2007). As there was no commercial aquaculture of redclaw freshwater crayfish in Singapore, Ahyong \& Yeo (2007) concluded that the introduction was through the aquarium pet trade and deliberate or accidental release of the animals by the public. Tan et al. (2007) briefly mention a past (unsuccessful) aquaculture effort, but the initial stock for this originated from ornamental trade redclaws already in Singapore and no specific food stock was imported (P. K. L. Ng pers. comm.). Due to the role of freshwater crayfish as disease vectors and their potential ecological impacts, C. quadricarinatus was viewed by Ahyong \& Yeo (2007) as a possible major threat to Singapore's natural freshwater ecosystems and endemic freshwater fauna.

The main aim of the present study was to investigate the current status of Cherax quadricarinatus in Singapore's reservoirs. We present new distributional data on feral C. quadricarinatus, including findings from a Central Catchment Nature Reserve (CCNR) reservoir survey, an island-wide benthic freshwater macroinvertebrate survey, a decomposition study across 3 reservoirs, as well as museum records. Size-frequency distributions of the individuals collected were used to assess whether the current population structure indicates establishment or reproduction of this crayfish species in the reservoirs. Considering the source of introduction, a preliminary aquarium shop survey was performed to evaluate the current availability of the crayfish to the public. We discuss the implications of our findings on the possible ecological impact of $C$. quadricarinatus on the local freshwater environment.

\section{MATERIALS AND METHODS}

Study area. Singapore is a rapidly developing island city-state located at $1^{\circ} 15^{\prime} \mathrm{N}$, north of the equator, at the southern tip of the Malay Peninsula. Its land area of $\sim 700 \mathrm{~km}^{2}$ is densely populated (>7000 people per $\mathrm{km}^{2}$ ) and highly urbanized (MEWR 2008). Only a few natural freshwater habitats are left, as most of the lotic waterways have been heavily modified during the last $40 \mathrm{yr}$ into concrete drains through canalization (Tan et al. 2007). Singapore has no significant natural lentic water bodies (Wee \& Corlett 1986, Corlett 1992); instead the lentic environment comprises reservoirs, small quarry lakes and ponds in recreational parks, on 
golf courses and in gardens. The 13 artificial reservoirs in Singapore were constructed either by excavating swamp areas (e.g. Pandan Reservoir), damming the upper reaches of rivers (e.g. Upper Peirce, Lower Peirce, Upper Seletar and MacRitchie reservoirs), or by damming estuaries or river basins (e.g. Kranji, Lower Seletar, Murai, Tengeh, Sarimbun and Poyan reservoirs; Fig. 1). Many of the mainland reservoirs are internally connected with each other through concrete channels, drainages, or pipes, and they are managed primarily for domestic and industrial water supply (Appan 1992).

Of the remaining, comparatively undisturbed, freshwater habitats, the most important ones are found in Nee Soon swamp forest, covering an area of about $0.87 \mathrm{~km}^{2}$ in the CCNR (Ng \& Lim 1992) and in the Bukit Timah Nature Reserve (BTNR), just west of the CCNR (Tan et al. 2007). The CCNR consists of mostly secondary rain forest, although small patches of primary rainforest can still be found (Corlett 1997). The BTNR has been protected as a forest reserve since 1883, and is the only substantial remaining area of primary rain forest in Singapore (Wee \& Corlett 1986, Corlett 1992). The BTNR and Nee Soon swamp forest support a variety of freshwater environments, including narrow forest streams, small freshwater ponds and freshwater swamp that together harbour the highest percentage of endemic freshwater fish and freshwater macroinvertebrate species in Singapore ( $\mathrm{Ng}$ \& Wee 1994, Balke et al. 1997, Ng \& Lim 1997). Public access is regulated in both nature reserves, owing to their protected status.

Dedicated Cherax quadricarinatus survey in the CNNR. From August 2007 to February 2008, 3 CCNR reservoirs (Upper Peirce, Lower Peirce and Upper Seletar reservoirs) and the Nee Soon swamp forest were surveyed specifically for C. quadricarinatus, using traps to investigate whether this exotic species has undergone a range expansion (cf. Ahyong \& Yeo 2007). To standardize the sampling, all surveyed reservoirs were divided into 4 quadrants, and 2 randomly selected sampling sites in each quadrant were chosen, i.e. a total of 8 survey sites per reservoir. The traps used were collapsible rectangular wire cages $(600 \times$ $430 \times 180 \mathrm{~mm}^{3}, 25 \mathrm{~mm}^{2}$ mesh size), and 2 different sizes of bottle traps (diameters of 85 and $150 \mathrm{~mm}, 25 \times$ $13 \mathrm{~mm}^{2}$ mesh size) were baited with raw pig liver and squid. At each sampling station, 15 traps (5 of each type) were deployed in an alternating sequence along a $200 \mathrm{~m}$ transect roughly parallel to the shoreline at $\sim 2 \mathrm{~m}$ water depth. All traps were recovered after $24 \mathrm{~h}$. Only C. quadricarinatus were kept and brought back to the laboratory. In total, crayfish traps were deployed 3 times per site per reservoir at a $4 \mathrm{wk}$ interval. From November 2007 to February 2008, 8 sites in Nee Soon swamp forest were sampled following the same survey design of 3 trap types $\times 5$ replicates $\times 3$ sampling occasions. At the reservoirs and at Nee Soon swamp forest, water temperature, $\mathrm{pH}$ and dissolved oxygen $\left(\mathrm{mg} \mathrm{l}^{-1}\right)$ were recorded with a hand-held YSI 556 multi-probe. Three replicates of each parameter per sampling station and sampling date were taken just above the benthos.

Other studies: Cherax quadricarinatus obtained as incidental catch. From October to November 2008, C. quadricarinatus individuals were incidentally captured during a project to develop a biotic index for waterquality assessment across Singapore's lentic systems (Clews et al. 2010). During this period, 13 reservoirs and 2 quarry lakes were investigated (Fig. 1). Artificial substrates for collecting benthic freshwater macroinvertebrates were placed on the rocky bund in the littoral zone ( 1.5 m depth), as this was the only habitat

Fig. 1. Map of Singapore indicating the past (open circles) and present (filled squares) geographic distribution of Cherax quadricarinatus in the reservoirs. The number of reservoirs reflects the status quo of the year 2008, all indicated lentic systems were sampled at least once

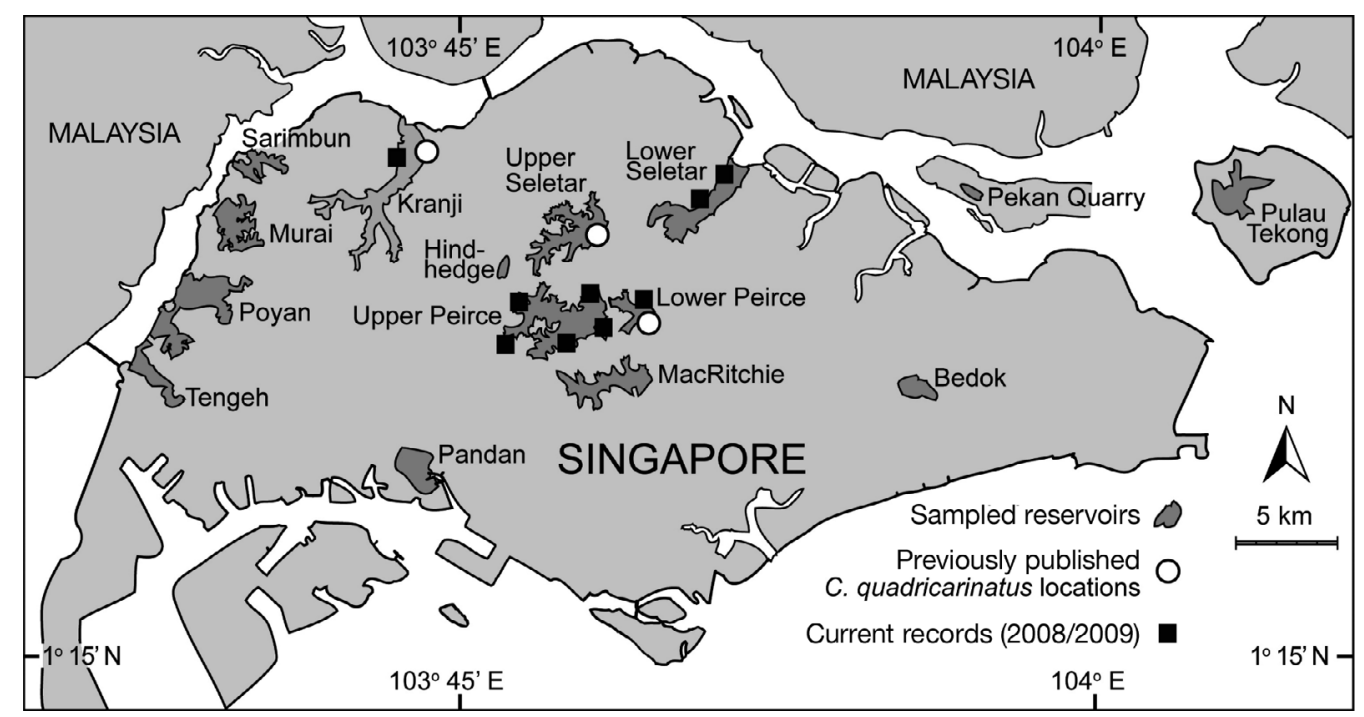


common to all reservoirs and quarry lakes. The mesocosms used consisted of wire-mesh cages $(200 \mathrm{~mm}$ diameter; $100 \mathrm{~mm}$ height, $12 \mathrm{~mm}^{2}$ mesh size) containing coconut toilet brushes and split palm fronds as artificial substrate (Loke et al. 2010). Five artificial substrate samplers were deployed along a $10 \mathrm{~m}$ transect for a duration of $4 \mathrm{wk}(30 \mathrm{~d})$ at 1 site in each of the reservoirs and quarry lakes.

From October to December 2008, more Cherax quadricarinatus individuals were incidentally caught during a decomposition study (N. Y. C. Yap et al. unpubl. data), which investigated vegetated sites with silty or sandy benthic substrate in 3 reservoirs (Kranji, Lower Seletar and Lower Peirce). The artificial substrate used consisted of plastic mesh leaf packets $\left(200 \times 200 \mathrm{~mm}^{2}\right.$ size, $5 \mathrm{~mm}^{2}$ mesh size) harbouring 3 different kinds of leaf litter deployed for up to 3 mo. Each time, 30 replicate leaf packets were retrieved after 4, 8 and $12 \mathrm{wk}$ of deployment. C. quadricarinatus juveniles were only found during the first retrieval period (4 wk).

During all surveys, the exact sampling date, location (GPS coordinates), sex and morphometric data (total body length, TBL, measured from the anterior tip of the rostrum to the posterior edge of the telson) were determined for all Cherax quadricarinatus specimens. Species identification was performed using the identification key provided by Horwitz (1995) and the figures and diagnostic features reported by Jones \& Morgan (1994). All samples were subsequently deposited as voucher specimens at the Zoological Reference Collection (ZRC) of the Raffles Museum of Biodiversity Research, National University of Singapore.

For both the biotic index and decomposition study, water temperature, $\mathrm{pH}$ and dissolved oxygen $\left(\mathrm{mg} \mathrm{l}^{-1}\right)$ were recorded in situ with a hand-held YSI 556 multiprobe. Total hardness, as an important factor for mineralization of the crayfish exoskeleton, as well as ammonium and nitrate concentration were measured in vitro by a laboratory certified by the American Public Health Association (Setsco Pte Ltd) within $8 \mathrm{~h}$ of the water sample collection (phenate method and ion chromatography, respectively; APHA 1995). Three replicates were taken at the actual time of artificial substrate sampler deployment and again after $4 \mathrm{wk}$.

Cherax quadricarinatus museum samples. In the ZRC, the catalogued and non-catalogued Singaporean freshwater macroinvertebrate collection (1993 up to 2007) was searched thoroughly for preserved C. quadricarinatus. The exact location, collection date and morphometric data of all specimens were recorded. In addition, the complete crustacean collection of the ZRC was explored to trace the first historical records of C. quadricarinatus in Singapore based on preserved specimens (including specimens purchased from the aquarium trade).

\section{RESULTS}

Altogether, 50 sites in 13 reservoirs and 2 quarry lakes were sampled in Singapore's water supply catchments, including 8 stations in Nee Soon swamp forest. Overall, 83 Cherax quadricarinatus individuals from 9 sites in 4 reservoirs were collected (Table 1). New reservoir records (Upper Peirce and Lower Seletar reservoirs) and new site records have been added to the previously published distribution (Ahyong \& Yeo 2007) to illustrate the current $C$. quadricarinatus range in Singapore (Fig. 1).

Previous records of feral Cherax quadricarinatus from Kranji and Lower Peirce reservoirs were verified, but we did not catch any specimens at Upper Seletar reservoir, from which they had been previously reported (Ahyong \& Yeo 2007). Eleven juvenile C. quadricarinatus were collected in Kranji reservoir at 1 sampling location, confirming the previous published records. However, the second location, $1.5 \mathrm{~km}$ further south in this reservoir, yielded no C. quadricarinatus specimens. The establishment of C. quadricarinatus is confirmed for Upper Peirce and Lower Seletar reservoirs. Forty-nine adult C. quadricarinatus were captured at 5 randomly selected sampling sites in Upper Peirce reservoir. Twenty-two individuals were captured at 2 sampling locations in Lower Seletar reservoir (Fig. 2, Table 2). Despite the greater freshwater macroinvertebrate sampling effort in Lower Peirce reservoir (3 studies comprising 10 different sites; Table 1) compared to other reservoirs, just 1 C. quadricarinatus individual was captured. No C. quadricarinatus were found at Nee Soon swamp forest, and no ovigerous females were obtained in any of the surveys.

The Cherax quadricarinatus caught represented stages from early juvenile to adult (TBL range: 6.52 to $175.88 \mathrm{~mm}$ ). For C. quadricarinatus captured in Kranji and Lower Seletar reservoirs, the TBL ranged from 12 to $96.4 \mathrm{~mm}$ (mean TBL \pm SE: $38.5 \pm 9.7 \mathrm{~mm}$ ) and from 6.5 to $44.8 \mathrm{~mm}$ (mean \pm SE TBL: $20.4 \pm 2.9 \mathrm{~mm}$ ), indicating that samples from both reservoirs represented primarily juvenile stages (Fig. 2, Table 2). In Upper Peirce reservoir, the sampled individuals' sizes ranged from 41.3 to $175.9 \mathrm{~mm}$ (mean \pm SE TBL: $114.7 \pm$ $5.5 \mathrm{~mm}$ ), thus representing adults. As reported elsewhere (e.g. Lawrence \& Jones 2002), males were larger than females (average \pm SE TBL: $86.19 \pm 5.2 \mathrm{~mm}$ for males and $71.89 \pm 6.5 \mathrm{~mm}$ for females). The lengthfrequency distribution shows a continuous pattern, with 4 cohorts present if all collected reservoir specimens are pooled (Fig. 2).

At Cherax quadricarinatus collection sites, the average $\mathrm{pH}$ ranged from 8.0 to 8.7, compared to Nee Soon swamp forest, which displayed a lower $\mathrm{pH}$ range of 4.9 to 5.5. The temperature recorded in all lentic water 

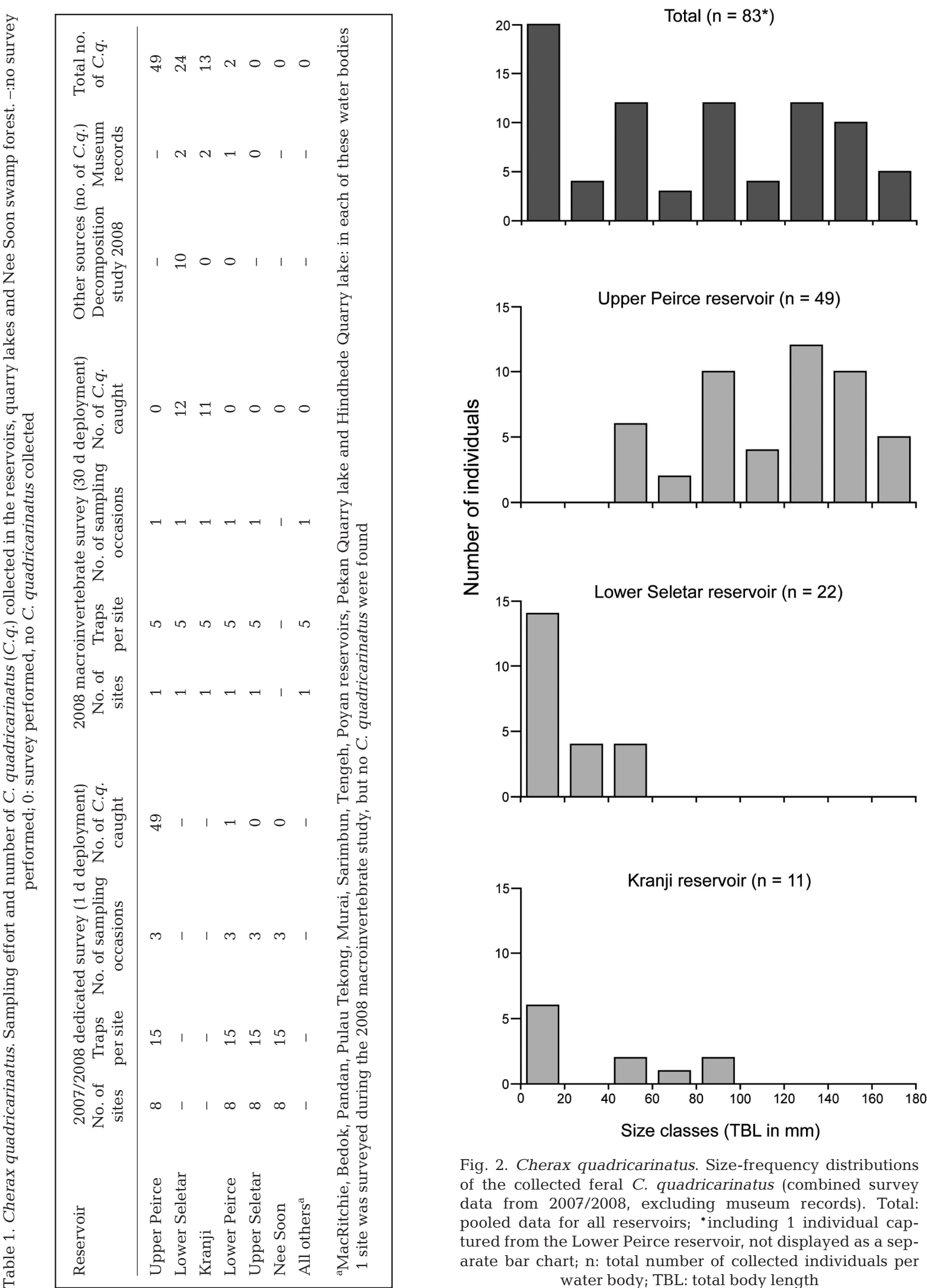

Fig. 2. Cherax quadricarinatus. Size-frequency distributions of the collected feral $C$. quadricarinatus (combined survey data from 2007/2008, excluding museum records). Total: pooled data for all reservoirs; *including 1 individual captured from the Lower Peirce reservoir, not displayed as a separate bar chart; $\mathrm{n}$ : total number of collected individuals per water body; TBL: total body length 
Table 2. Cherax quadricarinatus. Morphometric data, sampling dates and abiotic parameters (average \pm SE) at the time of collection. Waterquality data for the other reservoirs and quarry lakes is not shown, as the values lie in the range of the 3 reported reservoirs. na: data not available. F: females; M: males

\begin{tabular}{|c|c|c|c|c|c|c|c|c|c|c|}
\hline \multirow{2}{*}{ Reservoir } & \multirow{2}{*}{ Sampling date } & \multicolumn{4}{|c|}{ - Morphometrics } & \multirow[b]{2}{*}{$\begin{array}{c}\text { Hardness } \\
\left(\mathrm{CaCO}_{3}\right. \\
\left.\mathrm{mg} \mathrm{l}^{-1}\right)\end{array}$} & \multirow[b]{2}{*}{$\begin{array}{c}\text { Ammonium } \\
\left(\mathrm{NH}_{3} \mathrm{~N}\right. \\
\left.\mathrm{mg} \mathrm{l}^{-1}\right)\end{array}$} & Water quality & \multirow{2}{*}{$\begin{array}{l}\mathrm{y} \\
\text { Temperature } \\
\left({ }^{\circ} \mathrm{C}\right)\end{array}$} & \multirow[b]{2}{*}{$\mathrm{pH}$} \\
\hline & & $\begin{array}{l}\text { No. of } \\
\text { ind. }\end{array}$ & $\begin{array}{l}\text { Total body } \\
\text { length } \\
\text { (mm) }\end{array}$ & $\begin{array}{l}\text { Sex } \\
\text { ratio } \\
(\mathrm{F}: \mathrm{M})\end{array}$ & $\begin{array}{l}\text { Dissolved } \\
\text { oxygen } \\
\left(\mathrm{mg} \mathrm{l}^{-1}\right)\end{array}$ & & & $\begin{array}{c}\text { Nitrate } \\
\left(\mathrm{NO}_{3} \mathrm{~N}\right. \\
\left.\mathrm{mg} \mathrm{l}^{-1}\right)\end{array}$ & & \\
\hline Upper Peirce & Jun-Nov 2007 & 49 & $41.3-175.9$ & 1:1.1 & $7.0 \pm 0.5$ & $16.3 \pm 2.6$ & $0.084 \pm 0.025$ & $0.14 \pm 0.02$ & $30.0 \pm 0.2$ & $8.0 \pm 0.5$ \\
\hline Kranji & Sep-Oct 2008 & 11 & $12-96.4$ & $1: 1.2$ & $5.1 \pm 0.2$ & $54.3 \pm 3.6$ & $<0.01^{\mathrm{a}}$ & $0.085 \pm 0.01$ & $30.0 \pm 0.2$ & $8.0 \pm 0.7$ \\
\hline Lower Seletar & Sep-Oct 2008 & 22 & $6.5-44.8$ & $1: 1.1$ & $7.3 \pm 0.3$ & $72.6 \pm 5.4$ & $0.033 \pm 0.01$ & $<0.015^{\mathrm{a}}$ & $30.0 \pm 0.2$ & $8.7 \pm 0.3$ \\
\hline Nee Soon & Nov 2007-Feb 2008 & $8-$ & - & na & $4.2 \pm 1.8$ & na & na & na & $25.6 \pm 0.1$ & $5.0 \pm 0.02$ \\
\hline
\end{tabular}

bodies was $\sim 30^{\circ} \mathrm{C}\left( \pm 0.2^{\circ} \mathrm{C} \mathrm{SE}\right)$ and slightly lower in Nee Soon swamp forest (average $\pm \mathrm{SE}: 25.6 \pm 0.1^{\circ} \mathrm{C}$ ). Total hardness and ammonium and nitrate concentrations varied slightly among the reservoirs, but readings were generally low (Table 2).

The ZRC crustacean collection holds several historical records of Cherax quadricarinatus in Singapore. The oldest sample (ZRC 1990.433-434), dated 1989, contained 1 male and 1 ovigerous female crayfish and was labelled 'Cherax quadricarinatus, from Australia, Aquarium trade specimen, Coll.: Ng, Peter, Aug 1989; Id: C. Austin, 5th April 2002'. Five additional Australian aquarium trade specimens (ZRC 2001.0775) were added to the crustacean collection in 2001 and 2002. In April 2001 and April 2002, the first specimens were collected from reservoirs. The oldest reservoir museum sample originated from Kranji reservoir and contained 2 mid-sized males (ZRC 2001.1109, TBL 108.98 and $115.1 \mathrm{~mm})$. Subsequently, in 2002, one immature individual (ZRC 2002.0272, TBL $41.62 \mathrm{~mm}$ ) was collected in Lower Peirce reservoir. In addition, the unsorted ZRC freshwater collection contained 2 individual C. quadricarinatus collected in 2007 from Lower Seletar reservoir.

\section{DISCUSSION}

Here we provide data confirming the further range expansion of feral Cherax quadricarinatus within Singapore into 1 CCNR reservoir (Upper Peirce) and 1 coastal reservoir (Lower Seletar). The continuing presence of C. quadricarinatus in Kranji reservoir previously reported by Ahyong \& Yeo (2007) is confirmed. Further, we provide the first in situ population data for feral $C$. quadricarinatus populations originating from the ornamental or aquarium pet species trade. The widespread presence of $C$. quadricarinatus was first noticed in 2000 when many people, mostly recre- ational fishermen, observed the crayfish in Lower Peirce, Upper Seletar and Kranji reservoirs (Ahyong \& Yeo 2007). The first physical evidence for the presence of feral C. quadricarinatus, in the form of ZRC specimens collected from Kranji and Lower Peirce reservoirs, dates back as far as 2001.

\section{Geographic distribution, abiotic parameters and morphometry of Cherax quadricarinatus in Singapore}

The year-long presence of Cherax quadricarinatus in Kranji reservoir and the discovery of established and reproducing populations in 2 additional reservoirs (Upper Peirce and Lower Seletar) since the first published records in 2007 illustrate that Singapore's lentic waters are able to support C. quadricarinatus. The observed intra-reservoir variation or patchy distribution pattern within water bodies can probably be explained either by the availability of suitable littoral habitat, especially macrophytes and shelter (Fielder \& Thorne 1990, Jones \& Ruscoe 2001), or by differences in human activity across the reservoirs - specifically, the recurring introduction of crayfish, a major dispersal factor, contributes to the current geographic distribution.

Despite the increased sampling effort in the Lower Peirce and Upper Seletar reservoirs in comparison to other reservoirs, we could not confirm the ongoing presence of 2 feral populations previously reported there. There are several potential explanations for this result. First, we might simply have missed the existing populations. However, the enhanced sampling effort and the intra-reservoir distribution of the sampling locations (see Table 1) makes it unlikely that we would have overlooked feral populations in those 2 reservoirs. It is possible that the management regimes in the Lower Peirce and Upper Seletar reservoirs, 
especially the exhaustive dredging of macrophytes and constant removal of fallen timber over the last 2 yr, have created a suboptimal habitat for the persistance of Cherax quadricarinatus. Well-documented exotic species population collapses are rare (reviewed by Simberloff \& Gibbons 2004), and, as no past demographic data could be retrieved about the former $C$. quadricarinatus populations at Lower Peirce and Upper Seletar reservoirs, the causes of their disappearance remain unclear.

The abiotic parameters measured during the surveys show that the water chemistry and water temperature in the reservoirs provide a suitable environment for Cherax quadricarinatus (King 1994, Jones 1995). Conversely, Nee Soon Swamp forest is characterised by low pH surface waters (Table 2), and C. quadricarinatus would not be able to establish and persist under such conditions (King 1994, Jones 1995). As Singapore's reservoirs are managed as drinking water supplies, ammonium and nitrate concentrations were generally low, and well below the mean lethal concentration for C. quadricarinatus (Meade \& Watts 1995).

Observed mean size and size ranges of the collected Cherax quadricarinatus differed between the reservoirs, but all lie within the range of values reported for this species (TBL from 6 to $200 \mathrm{~mm}$; Lawrence \& Jones 2002). The presence of all cohorts ranging from 40 up to $180 \mathrm{~mm}$ TBL at Upper Peirce reservoir (Fig. 2) indicates that $C$. quadricarinatus has established a population with overlapping generations (Caddy 1987). Data are insufficient to draw the same conclusions for Lower Seletar and Kranji reservoirs. However, the large proportion of early juveniles (TBL $<20 \mathrm{~mm}$ ) captured during the biotic index survey suggests reproducing populations in those 2 reservoirs as well.

No ovigerous female was collected, but this is not surprising as gravid females tend to be cautious, cryptic and avoid congeners during the period of breeding and maternal care (Levi et al. 1999, Reynolds 2002). Furthermore, Cherax quadricarinatus reproduction in the native range is seasonal (Doupé et al. 2004). Even though year-round reproduction of C. quadricarinatus has been reported in laboratory trials (Sammy 1988, Jones 1990, Barki et al. 1997), in most cases, the spawning cycle corresponded to the seasonal pattern in the native range when the initial temperature and/ or light regime was stopped (Yeh \& Rouse 1994, Barki et al. 1997). Hence, a seasonal reproductive pattern for feral C. quadricarinatus populations in Singapore based on seasonality of the source population cannot be discounted. Native C. quadricarinatus populations reproduce between March and September (Doupé et al. 2004), a period that we did not cover in our surveys. However, the relatively high abundance of early juvenile crayfish (TBL $<20 \mathrm{~mm}$ ) caught in the Lower Sele- tar and Kranji reservoirs in October 2008 is consistent with C. quadricarinatus in Singapore following the spawning periodicity of native populations.

\section{Invasion pathway, vectors and establishment}

Singapore's import of Cherax quadricarinatus is exclusively for ornamental trade (Agri-Food \& Veterinary Authority of Singapore, pers. comm.), and the only likely means of $C$. quadricarinatus entering Singapore's reservoirs is deliberate release by the public or accidental escape. The current geographic distribution also suggests these are the main dispersal vectors, as all C. quadricarinatus sites in the reservoirs are either easily accessible by the public (dams, road sides, or public fishing areas at Upper and Lower Peirce, Upper and Lower Seletar, and Kranji reservoirs), or border golf courses (Lower Seletar and Upper Peirce reservoirs).

The ready availability of Cherax quadricarinatus in aquarium or pet shops can be viewed as one important direct indicator of propagule pressure and, therefore, as a linear predictor of establishment success (Duggan et al. 2006, Copp et al. 2007). A preliminary islandwide survey of 50 haphazardly selected aquarium shops showed $44 \%$ stocked C. quadricarinatus. Even though there are multiple subtropical and tropical freshwater crayfish species in trade in Singapore, for example, the North American Procambarus clarkii, the Australian Cherax tenuimanus, C. destructor and $C$. cainii, and C. peknyi, C. holthuisi and C. boesemani originating from Papua New Guinea (Ahyong \& Yeo 2007, Yeo 2010), the only species that has established feral populations so far is the largest species, with its exceptional reproduction and growth rate: C. quadricarinatus. This observation parallels the patterns described for invasion success of aquarium fish in North America, where introduced and established taxa are typically larger in relation to individuals of the same genus, or in relation to other species available in stores (Duggan et al. 2006).

The actual number of feral Cherax quadricarinatus populations reported elsewhere (see Table 3) seems low considering the number of tropical and neotropical countries the species has been relocated to through aquaculture. Having an approximate lag time (the time in years between the first documented introduction and detected naturalization of an exotic species; Kowarik 1995) of 12 yr between introduction and naturalization in Singapore, the establishment or detection of feral C. quadricarinatus populations would appear to take longer if the ornamental trade was the anthropogenic vector of translocation (Table 3). 'Time lags' can have several reasons (Crooks 2005), but our data are too scarce to draw any further conclusions. 
Table 3. Recent citations documenting the different anthropogenic vectors, years of introduction, first documented feral occurrences in the adventive area and time lags between introduction and naturalization (in years, sensu Kowarik 1995) of naturalized C. quadricarinatus populations

\begin{tabular}{|c|c|c|c|c|c|}
\hline Country & Vector of introduction & $\begin{array}{c}\text { Year of } \\
\text { introduction }\end{array}$ & $\begin{array}{c}\text { Year of first } \\
\text { documented naturalization }\end{array}$ & $\begin{array}{l}\text { Time } \\
\operatorname{lag}(y r)\end{array}$ & Source(s) \\
\hline Jamaica & Aquaculture & 1993 & 1999 & 6 & $\begin{array}{l}\text { Townsend \& Newell } \\
\text { 2006, Wong } 2007\end{array}$ \\
\hline Mexico & Aquaculture & 1995 & 2000 & 5 & Bortolini et al. 2006 \\
\hline Namibia $^{\mathrm{a}}$ & Aquaculture & 1997 & 2004 & 7 & Bethune et al. 2004 \\
\hline Puerto Rico ${ }^{b}$ & Aquaculture (illegal stocking) & 1997 & 1998 & 1 & $\begin{array}{l}\text { Williams et al. 2001, } \\
\text { Vazquez } 2008\end{array}$ \\
\hline Singapore & Ornamental trade & 1989 & 2001 & 12 & $\begin{array}{l}\text { Ahyong \& Yeo } 2007, \\
\text { Tan et al. } 2007, \\
\text { present study }\end{array}$ \\
\hline South Africa & Aquaculture & Late 1990 & 2002 & $\sim 5$ & de Moor 2002 \\
\hline
\end{tabular}

\section{Potential ecological impact on Singapore's natural environment}

Few studies have tried to address the possible effects of established Cherax quadricarinatus populations on the freshwater ecosystem of the adventive areas (de Moor 2002, Bortolini et al. 2006, Vazquez 2008). Singapore has no native crayfish, although the now locally extinct giant freshwater prawn Macrobrachium rosenbergii potentially occupied a similar niche in large rivers and open-water habitats ( $\mathrm{Ng} \&$ Lim 1997). Therefore, C. quadricarinatus in Singapore is an introduced multitrophic keystone species in a, more or less, artificially created environment. In general, major ecological impacts caused by introduced crayfish species include loss of native biodiversity and changes in ecosystem functioning (Nyström et al. 1996, Holdich et al. 1999). Like many other crayfish, C. quadricarinatus are known to readily disperse or move up- and downstream if densities are too high (Doupé et al. 2004, Bortolini et al. 2006). In Singapore, redclaws could potentially spread along the drainage system and concrete channels connecting the reservoirs with nature reserves. This poses a severe threat to the more natural Singaporean freshwater environment, as most of the drainages originate either in the CCNR or BTNR. Although adult $C$. quadricarinatus selectively feed on decaying plant material, juvenile redclaws are opportunistic and active predators of zooplankton (LoyaJavellana et al. 1993). Both modes of feeding might have a negative impact on the native macroinvertebrate community through habitat alteration, competition and changes in the food web. However, no data are yet available about the effect of naturalized
C. quadricarinatus populations on algae, macrophytes, amphibians and fishes (Doupé et al. 2004).

There is no evidence so far of displacement of any native macroinvertebrate species by Cherax quadricarinatus in Singapore. In Puerto Rico (Vazquez 2008) and in the Singaporean biotic index samples (Clews et al. 2010), the presence or absence of C. quadricarinatus did not change the species diversity or the richness of aquatic macroinvertebrates of other trophic levels. Moreover, there is no indication yet that established C. quadricarinatus populations out-compete native crayfish or other indigenous decapods in Puerto Rico, or in Mexico, where C. quadricarinatus are found cooccurring with native freshwater prawns Macrobrachium spp. of approximately the same size (Bortolini et al. 2006, Vazquez 2008). In contrast, invasive C. quadricarinatus in the Black River catchment in Jamaica seem to cause substantial ecological and economic damage due to the replacement of, and predation on, native shrimps (Wong 2007). However, it is not known whether the competitive advantage is due to cultural-induced human overfishing of the native shrimp species or a real competitive advantage of C. quadricarinatus. More experimental research, for example, using artificial microcosms (see Nyström et al. 1999), is needed to assess the influence of established C. quadricarinatus on the benthic communities in invaded areas.

A major concern with introduced Cherax quadricarinatus in Singapore is its potential role as a parasite and disease vector. In Africa, North America and East Asia, crayfish, like other freshwater decapods, are known to be the secondary intermediate hosts of parasitic flatworms, such as lung flukes of the genus Paragonimus, that can be transmitted to vertebrates, includ- 
ing humans, if the crayfish are consumed raw (Lane et al. 2009 and references therein). Moreover, C. quadricarinatus hosts a variety of symbiotic and parasitic microbes and invertebrates that are not strictly host species specific (Edgerton \& Owens 1999, Edgerton et al. 2002). For example, the rickettsia-like microbes that are found in redclaw aquaculture are explicitly linked to a variety of infectious diseases in vertebrates, including humans (Romero \& Jimenez 2002). The impact of diseases and parasites carried by C. quadricarinatus on Singapore's native decapod crustaceans remains uncertain and is compounded by the lack of knowledge about native crustacean diseases and parasites. If introduced, there is no dispersal barrier for waterborne symbionts between the reservoirs and the remaining natural freshwater environments that harbour the highest diversity of endemic crustacean fauna.

\section{CONCLUSIONS}

Owing to the low abundance and unlikely establishment success in acid waters, it may be too early to state that the current Cherax quadricarinatus presence and distribution constitutes an immediate danger for Singapore's natural freshwater environment. According to their geographic distribution, the C. quadricarinatus populations are still restricted to artificial lakes, which already support high numbers of exotic species (e.g. of freshwater fish species, $50 \%$ are non-indigenous; $\mathrm{Ng}$ et al. 1993, see also Ng \& Lim 2010, Ng \& Tan 2010, Yeo 2010, Yeo \& Chia 2010). Presently, the different abiotic conditions between the reservoirs (relatively alkaline waters) and the natural forest streams and swamp in the nature reserves (relatively acidic waters) seem to provide a sufficient barrier to a range expansion of C. quadricarinatus into Singapore's natural freshwater systems.

Very little is currently known about the macroinvertebrate communities of tropical lentic systems (Dudgeon 2003), including Singapore, where entire freshwater ecosystems have been modified over the last $40 \mathrm{yr}$ to suit the demands of a rapidly growing metropolis. Owing to this habitat alteration, the reservoirs are 'exotic species heavens' as they provide a novel environment, which differs from the native, acid forest to which stream-inhabiting species are adapted (e.g. Ng et al. 1993, Ng \& Lim 2010, Ng \& Tan 2010, Yeo 2010), and in which invasions appear to be more likely because empty niches are available (Hierro et al. 2005, Paavola et al. 2005). The reservoirs might also more closely resemble the native ecosystems of exotic species, helping them overcome the 'environmental filter' (Richardson et al. 2000) and favouring subsequent establishment (Kolar \& Lodge 2002, Hayes \& Barry
2007). Therefore, the reservoirs already, and in the future, may act as secondary sources, which would facilitate establishment and subsequent range expansion of exotic species into Singapore's other freshwater habitats (e.g. Tan \& Lim 2008).

In general, the only successful approach to prevent invasive species establishment is to stop them from entering the ecosystem and becoming fully established. To a certain extent, prevention might be possible through education, guidance, or legal controls on the aquarium trade in Singapore, as already practiced, for example, in the case of endangered freshwater turtle species (Goh \& O'Riordan 2007). After establishment, management efforts are usually very expensive and often ineffective (Lodge et al. 2006). Although current legislation prohibits the release of animals in Singapore's nature reserves, including the CCNR reservoirs, the enforcement of these laws is a challenge. As the range of redclaws in Singapore is still expanding (Yeo 2010), swift action is needed to assess, and, if necessary, control the potentially harmful island-wide metapopulation of Cherax quadricarinatus.

Acknowledgements. The biotic index study was funded by the Public Utilities Board (PUB) Grant R 154-000-384-490, and this financial support is acknowledged. We are grateful to the PUB, Singapore, and the National Parks Board (Nparks), Singapore, for providing the boats and issuing the permits for collection in the nature reserves and reservoirs. The fieldwork was done with the kind collaboration and interest of the PUB staff and boatmen at the reservoirs. We also thank S. K. Tan, M. Low and H. K. Lua for their support in sourcing the ZRC museum collection. Many thanks to 2 anonymous reviewers for their suggestions and comments, which helped to improve an earlier version of this article.

\section{LITERATURE CITED}

Ahyong ST, Yeo DCJ (2007) Feral populations of the Australian red-claw crayfish (Cherax quadricarinatus von Martens) in water supply catchments of Singapore. Biol Invasions 9:943-946

Alfred ER (1961) Singapore freshwater fishes. Malay Nat J 15: $1-19$

Alfred ER (1966) The fresh-water fishes of Singapore. Zool Verh 78:1-8

APHA (American Public Health Association) (1995) Standard methods for the examination of water and wastewater, 19th edn. APHA, Washington, DC

Appan A (1992) The control of water quality in Singapore. In: Gupta A, Pitts J (eds) Physical adjustments on a changing landscape. The Singapore story. Singapore University Press, Singapore

AVA (Agri-Food \& Veterinary Authority of Singapore) (2010) FY2008/09 annual report. Available at: www.ava.gov.sg/ publications (accessed on 12 February 2010)

Balke M, Henrich L, Yang CM (1997) Water beetles (Insecta: Coleoptera) in the nature reserves of Singapore. Gard Bull (Singap) 49:321-331

Barki A, Levi T, Hulata G, Karplus I (1997) Annual cycle of 
spawning and molting in the red-claw crayfish, Cherax quadricarinatus, under laboratory conditions. Aquaculture 157:239-249

Bethune S, Griffin M, Joubert D (2004) National review of invasive alien species, Namibia. Ministry of Environment and Tourism, Windhoek

Bortolini JL, Alvarez F, Rodriguez-Almaraz G (2006) On the presence of the Australian redclaw crayfish, Cherax quadricarinatus, in Mexico. Biol Invasions 9:615-620

Caddy J (1987) Size-frequency analysis for Crustacea: moult increment and frequency models for stock assessment. Kuwait Bull Mar Sci 9:43-61

> Clements R, Koh LP, Lee TM, Meier R, Li D (2006) Importance of reservoirs for the conservation of freshwater molluscs in a tropical urban landscape. Biol Conserv 128:136-146

Clews E, Low E, Belle C, Loke L and others (2010) A pilot biotic index for reservoir water quality assessment. Public Utilities Board, Singapore

Copp GH, Templeton M, Gozlan RE (2007) Propagule pressure and the invasion risks of non-native freshwater fishes: a case study in England. J Fish Biol 71:148-159

Corlett RT (1992) The ecological transformation of Singapore 1819-1990. J Biogeogr 19:411-420

Corlett RT (1997) The vegetation in the nature reserves of Singapore. Gard Bull (Singap) 49:147-159

Courtenay WR Jr, Robins CR (1975) Exotic organisms: an unsolved, complex problem. Bioscience 25:306-313

Crooks JA (2005) Lag times and exotic species: the ecology and management of biological invasions in slow-motion. Ecoscience 12:316-329

de Moor I (2002) Potential impacts of alien freshwater crayfish in South Africa. Afr J Aquat Sci 27:125-139

Dehnen-Schmutz K, Touza J, Perrings C, Williamson M (2007) The horticultural trade and ornamental plant invasions in Britain. Conserv Biol 21:224-231

Doupé RG, Morgan DL, Gill HS, Rowland AJ (2004) Introduction of redclaw crayfish Cherax quadricarinatus (von Martens) to Lake Kununurra, Ord River, Western Australia: prospects for a 'yabby' in the Kimberley. J R Soc West Aust 87:187-191

Dudgeon D (2003) The contribution of scientific information to the conservation and management of freshwater biodiversity in tropical Asia. Hydrobiologia 500:295-314

Duggan IC, Rixon CAM, MacIsaac HJ (2006) Popularity and propagule pressure: determinants of introduction and establishment of aquarium fish. Biol Invasions 8:377-382

Edgerton BF, Owens L (1999) Histopathological surveys of the redclaw freshwater crayfish, Cherax quadricarinatus, in Australia. Aquaculture 180:23-40

Edgerton BF, Evans LH, Stephens FJ, Overstreet RM (2002) Synopsis of freshwater crayfish diseases and commensal organisms. Aquaculture 206:57-135

Fielder DR, Thorne MJ (1990) Are shelters really necessary? Aust Fish 49:26-28

> Goh TY, O'Riordan RM (2007) Are tortoises and freshwater turtles still traded illegally as pets in Singapore? Oryx 41: 97-100

Hayes KR, Barry SC (2007) Are there any consistent predictors of invasion success? Biol Invasions 10:483-506

> Hierro JL, Maron JL, Callaway RM (2005) A biogeographical approach to plant invasions: the importance of studying exotics in their introduced and native range. J Ecol 93: $5-15$

> Holdich DM, Pöckel M (2005) Round table session. 2. Does legislation work in protecting vulnerable species? Bull Fr Peche Piscicult 376/377:809-827

Holdich DM, Ackefors H, Gherardi F, Rogers WD, Skurdal J
(1999) Native and alien crayfish in Europe: some conclusions. In: Gherardi F, Holdich DM (eds) Crayfish in Europe as alien species. How to make the best of a bad situation? AA Balkema, Rotterdam, p 2811-2892

Horwitz P (1995) Preliminary key to the species of Decapoda (Crustacea, Malacostraca) found in Australian inland waters. Co-operative Research Centre for Freshwater Ecology, Albury

Jones CM (1990) The biology and aquaculture potential of the tropical freshwater crayfish Cherax quadricarinatus. Information Series Q 190028, Queensland Department of Primary Industries, Brisbane

Jones CM (1995) Production of juvenile redclaw crayfish, Cherax quadricarinatus (von Martens) (Decapoda, Parastacidae). III. Managed pond production trials. Aquaculture 138:247-255

Jones DS, Morgan GJ (1994) A field guide to crustaceans of Australian waters. Reed, Sydney

Jones CM, Ruscoe IM (2001) Assessment of five shelter types in the production of redclaw crayfish Cherax quadricarinatus (Decapoda: Parastacidae) under earthen pond conditions. J World Aquacult Soc 32:41-52

Karplus I, Zoran M, Milstein A, Harpaz S, Eran Y, Joseph D, Sagi A (1998) Culture of the Australian red-claw crayfish (Cherax quadricarinatus) in Israel. III. Survival in earthen ponds under ambient winter temperatures. Aquaculture 166:259-267

King CR (1994) Growth and survival of redclaw hatchlings (Cherax quadricarinatus von Martens) in relation to temperature, with comments on the relative suitability of Cherax quadricarinatus and Cherax destructor for culture in Queensland. Aquaculture 122:75-80

Kolar CS, Lodge DM (2002) Ecological predictions and risk assessment for alien fishes in North America. Science 298: 1233-1236

Kowarik I (1995) Time lags in biological invasions with regard to the success and failure of alien species. In: Pysek $P$, Prach K, Rejmánek M, Wade PM (eds) Plant invasions: general aspects and special problems. SPB Academic, Amsterdam, p 15-38

Lane MA, Barsanti MC, Santos CA, Yeung M, Lubner SJ, Weil GJ (2009) Human paragonimiasis in North America following ingestion of raw crayfish. Clin Infect Dis 49: e55-e61

Lawrence C, Jones C (2002) Chapter 17: Cherax. In: Holdich DM (ed) Biology of freshwater crayfish. Blackwell, London, p 635-669

> Levi T, Barki A, Hulata G, Karplus I (1999) Mother-offspring relationships in the red-claw crayfish Cherax quadricarinatus. J Crustac Biol 19:477-484

Lodge DM, Williams S, MacIsaac HJ, Hayes KR and others (2006) Biological invasions: recommendations for U.S. policy and management. Ecol Appl 16:2035-2054

> Loke LHL, Clews E, Low E, Belle CC, Todd PA, Eikaas HS, Ng PKL (2010) Methods for sampling benthic macroinvertebrates in tropical lentic systems. Aquat Biol 10:119-130

> Loya-Javellana GN, Fielder DR, Thorne MJ (1993) Food choice by free-living stages of the tropical freshwater crayfish, Cherax quadricarinatus (Parastacidae: Decapoda). Aquaculture 118:299-308

> Mack RN, Simberloff D, Lonsdale WM, Evans H, Clout M, Bazzaz FA (2000) Biotic invasions: causes, epidemiology, global consequences, and control. Ecol Appl 10:689-710

Meade ME, Watts SA (1995) Toxicity of ammonia, nitrite, and nitrate to juvenile Australian crayfish, Cherax quadricarinatus. J Shellfish Res 14:341-346

MEWR (Ministry of the Environment and Water Resources) 
(2008) State of the environment report. Singapore MEWR, Singapore

$\mathrm{Ng} \mathrm{HH}$, Tan HH (2010) An annotated checklist of the nonnative freshwater fish species in the reservoirs of Singapore. Cosmos 6:95-116

$\mathrm{Ng} \mathrm{HH}$, Tan HH, Yeo DCJ, Ng PKL (2009) Stingers in a strange land: South American freshwater stingrays (Potamotrygonidae) in Singapore. Biol Invasions 12:85-88

Ng PKL, Lim KKP (1992) The conservation status of the Nee Soon freshwater swamp forest of Singapore. Aquat Conserv 2:255-266

Ng PKL, Lim KKP (1997) The diversity and conservation status of fishes in the nature reserves of Singapore. Gard Bull (Singap) 49:245-265

Ng PKL, Wee YC (1994) The Singapore Red Data book: threatened plants and animals of Singapore. Nature Society, Singapore

Ng PKL, Chou LM, Lam TJ (1993) The status and impact of introduced freshwater animals in Singapore. Biol Conserv 64:19-24

$\mathrm{Ng} \mathrm{TH}$, Lim KKP (2010) Introduced aquatic herpetofauna of Singapore's reservoirs. Cosmos 6:117-127

Nyström P, Brönmark C, Granéli W (1996) Patterns in benthic food webs: a role for omnivorous crayfish? Freshw Biol 36: 631-646

Nyström P, Brönmark C, Granéli W (1999) Influence of an exotic and a native crayfish species on a littoral benthic community. Oikos 85:545-553

Paavola M, Olenin S, Leppakoski E (2005) Are invasive species most successful in habitats of low native species richness across European brackish water seas? Estuar Coast Shelf Sci 64:738-750

Reynolds JD (2002) Growth and reproduction. In: Holdich DM (ed) Biology of freshwater crayfish. Blackwell, London, p 152-191

Richardson DM, Pysěk $P$, Rejmànek $M$, Barbour MG, Panetta FD, West CJ (2000) Naturalization and invasion of alien plants: concepts and definitions. Divers Distrib 6: 93-107

Rodriguez-Canto A, Arredondo-Figueroa JL, Ponce-Palafox JT, Rouse DB (2002) Growth characteristics of the Australian redclaw crayfish, Cherax quadricarinatus, cultured in an indoor recirculating system. J Appl Aquacult 12:59-64

Romero X, Jimenez R (2002) Histopathological survey of diseases and pathogens present in redclaw crayfish, Cherax quadricarinatus (von Martens), cultured in Ecuador. J Fish

Editorial responsibility: Sean Connell,

Adelaide, Australia
Dis 25:653-667

Sammy N (1988) Breeding biology of Cherax quadricarinatus in the Northern Territory. In: Evans LH, O'Sullivan D (eds) Proceedings of the 1st Australian shellfish aquaculture conference. Curtin University of Technology, Perth, p 79-88

Semmens BX, Buhle ER, Salomon AK, Pattengill-Semmens CV (2004) A hotspot of non-native marine fishes: evidence for the aquarium trade as an invasion pathway. Mar Ecol Prog Ser 266:239-244

> Simberloff D, Gibbons L (2004) Now you see them, now you don't - population crashes of established introduced species. Biol Invasions 6:161-172

Tan HH, Lim KKP (2008) Acarichthys heckelii (Mueller \& Troschel), an introduced cichlid fish in Singapore. Nat Singap 1:129-133

Tan HW, Chou LM, Yeo DCJ, Ng PKL (2007) The natural heritage of Singapore, 2nd edn. Prentice Hall, Singapore

Townsend S, Newell D (2006) Technical progress report IABIN invasive species thematic network content building project implement, update and maintain an I3N IAS database in Jamaica. Natural History Division Institute of Jamaica, Kingston

Vazquez SG (2008) Distribution of exotic Australian crayfish Cherax quadricarinatus (von Martens, 1868) in Puerto Rico. MSc thesis, University of Puerto Rico, Mayagüez

Wee YC, Corlett RT (1986) The city and the forest. Plant life in urban Singapore. Singapore University Press, Singapore

Williams EW Jr, Bunkley-Williams L, Lilyestrom CG, OrtizCorps EA (2001) A review of recent introductions of aquatic invertebrates in Puerto Rico and implications for the management of nonindigenous species. Caribb J Sci $37: 246-251$

Wong WY (2007) Of gods and government: What can Cherax quadricarinatus in Black River, Jamaica teach us about invasive species communication and management? Proc 15th Int Conf Aquat Inv Spec, Institute for inland water management and wastewater treatment (RIZA), Nijmegen, p 131

Yeh HS, Rouse DB (1994) Indoor spawning and egg development of the red claw crayfish Cherax quadricarinatus. J World Aquacult Soc 25:297-302

Yeo DCJ (2010) Introduced decapod crustaceans in Singapore's reservoirs. Cosmos 6:83-88

- Yeo DCJ, Chia CSW (2010) Introduced species in Singapore: an overview. Cosmos 6:23-37

Submitted: July 7, 2010; Accepted: January 24, 2011

Proofs received from author(s): March 18, 2011 